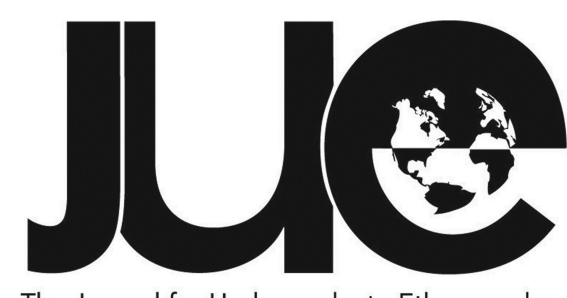

The Journal for Undergraduate Ethnography

\title{
"They are my babies": Meeting Mycobacterium tuberculosis and the Scientists Who Care for It
}

\section{Chloë-Sarah Shain}

University of Cape Town , chloe.shain1@gmail.com

\section{ABSTRACT}

Moving beyond what various scholars call the "human exceptionalism" in the social sciences, this multispecies research explored the relationships between Mycobacterium tuberculosis $(M t b)$ - the bacteria that is responsible for causing the disease Tuberculosis (TB) - and four molecular biologists who worked at a TB research centre in the Western Cape of South Africa. Using fingeryeyes, a conceptual and methodological tool derived by Eva Hayward (2010), the ethnographer participated through observation and touched through sight. In a space that was scientific there was care, in a space of risk there was nurture. In an environment of scientific lingo and hard-core jargon, parenthood emerged. Rather than Mtb microbes being solely subjects for experiments, they were babies that needed to be cared for. Making these babies was also making parents and scientists.

Keywords: multispecies, care, bacteria, fingeryeyes, social studies of science 


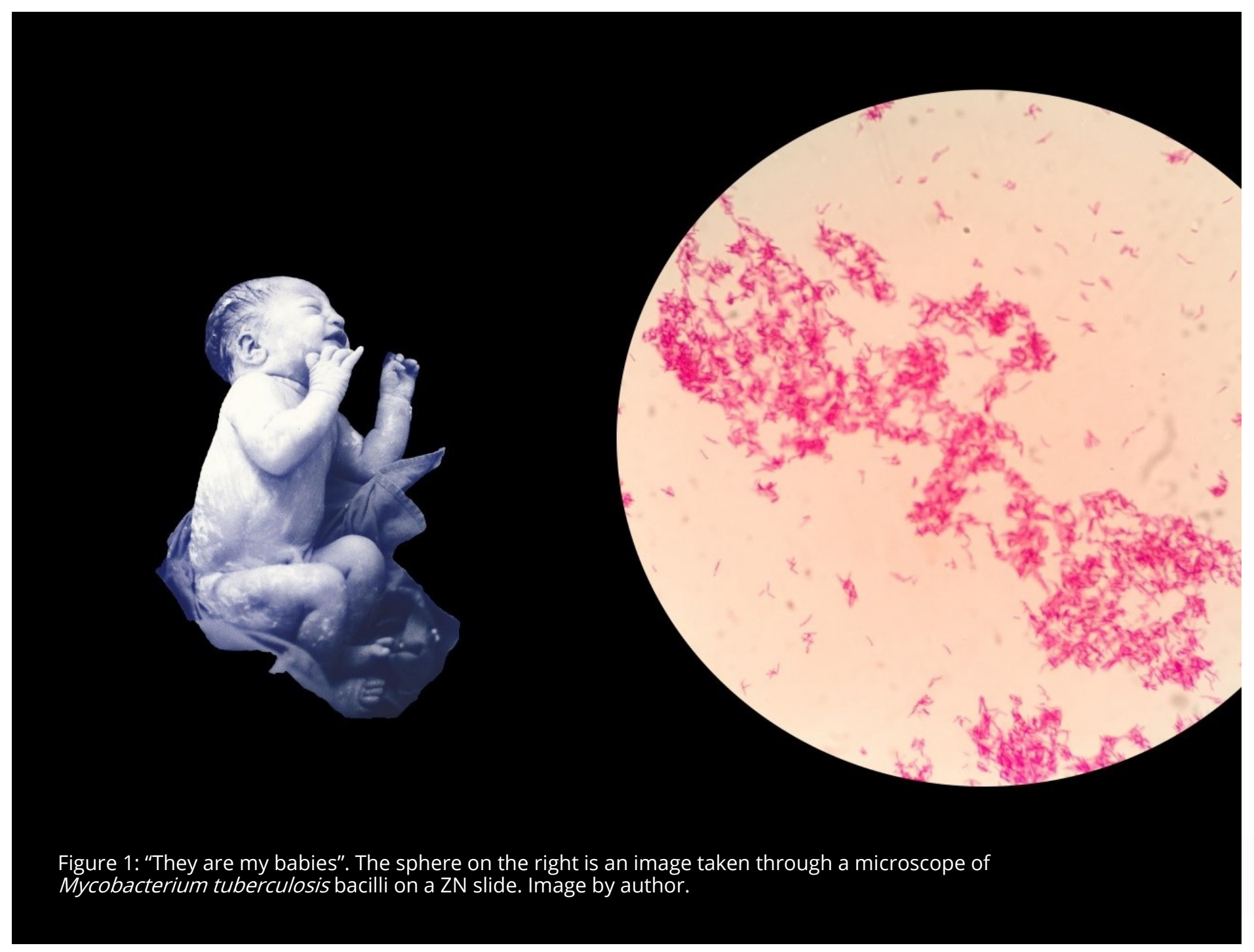

\section{Anthropologising the relationship between scientists and Mycobacterium tuberculosis}

M edical anthropologists have long been aware of the effect of microbes on the social, political, economic and cultural worlds of human beings, specifically with regard to infectious disease (Benezra et al. 2012, 6378). Less work has been done on human relationships with the microbes that are responsible for these diseases. Moving beyond what scholars call the "human exceptionalism" in the social sciences (Tsing 2012; Lowe 2010; Haraway 2008; Kirksey and Helmreich 2010), this research approached Tuberculosis (TB) from an alternative perspective. Rather than centring the human in relation to infection and disease, it centred multispecies relationships between Mycobacterium tuberculosis (Mtb) the bacterium that is responsible for causing the disease TB (see figure 3) - and four molecular biologists who worked at a TB research centre in the Western Cape of South Africa. Mtb is also referred to as the microbe, the bacterium, the bacillus or "the bug". "The bug" was a broad discursive category used by most of my research participants and other scientists in the TB research centre where I conducted my fieldwork.

Donna Haraway, in her book When Species Meet, writes,

The personal pronoun who... has nothing to do with derivative, Western, ethnocentric, humanist personhood for either people or animals, but rather has to do with the query proper to serious relationships among significant others, or, as I called them elsewhere, companion species, 
cum panis, messmates at a table together, breaking bread. The question between animals and humans here is, Who are you? and so, Who are we? $(2008,208)$

I query the relationship among significant others, revealing the notion of multispecies entanglement and companionship. This article extends "who" beyond humans in order to explore social relations that would otherwise be ignored if we continue to draw impenetrable boundaries between human and animal. The research on which this article is based involved studying the bacteria's social life in the laboratory, when it "met" - with specific reference to Haraway (2008) - the participants and the ethnographer. The "social" in this context follows Bruno Latour's (2005) discussion of Actor-Network-Theory (ANT), which calls for an expanded definition of the social beyond humans in order to trace the full range of networks and relations of which humans are a part. Eduardo Viveiros de Castro notes that "Another important consequence of having animals and other types of nonhumans conceived of as people - as kinds of humans is that the relations between the human species and most of what we would call 'nature' take on the quality of what we would term "social relations"' (2004, 465). I do indeed term the relations between my participants and $M t b$ "social relations" for this reason and therefore believe that they are worthy of anthropological attention.

Using participant observation, structured observation, informal conversation, interviews and "deep hanging out" (Geertz 1998), I followed the daily activities of scientists Amy, Tom, Nicole, and - less intensively, due to conferences and workshops that she had to attend overseas - Jana (all names of the scientists are pseudonyms). Each of them worked in specific areas of TB research. Amy was trying to see whether iron affected the growth of $M t b$. She created a mutant strain that was missing the protein that helps incorporate iron into other proteins in the bacteria. Tom's focus was the function of the proteins in the extracellular environment, the outermost layer of Mtb. Nicole's research involved the study of the intracellular bacteria, the bacteria taken up by the macrophages after infection with Mtb. Macrophages are the cells of the immune system that are formed in response to infections. Jana's work was in diagnostics and bioinformatics. At the time of my research, she was testing a machine that checked sputum samples for drug resistance.

In this article, I argue that rather than $M t b$ microbes being solely subjects for experiments, they were babies. Making these babies was also making parents and scientists.

\section{2. "It's not about curing, it's about understanding": The creation of a map and conveyor-belt science... a note on style}

I sat on a stool and watched Tom as he began doing his experiment. He explained that he was doing molecular cloning, which he described as the copying of DNA from one organism to another. In this case, it was copying DNA from Mtb to E.coli or Escherichia coli, which are mostly non-harmful bacteria found in stomachs and intestines. I asked Tom where his project would lead and what he hoped to accomplish with this experiment or series of experiments. I expected that his end goal was to eradicate TB, and that was what everybody in the research centre was working towards. Tom told me that “It's not about curing, it's about understanding... we all have a small part to figure out, hopefully it will lead to something bigger, but I don't think that far ahead." Each research participant's work was so focused and so different. Confused at how their work fit together, I asked Tom to explain.

"We're building a map," Tom told me one afternoon, "So we've charted a bit of South Africa and a bit of let's say Europe, but we don't know what's in between. But someone has to start... otherwise we won't have a map." These disparate parts of research - of the "map" - will eventually fit together, resulting in better understanding of the relationship between $M t b$ and the immune system to inform better drugs, better vaccines, better diagnostics and the eventual eradication of TB. This is not easy, and there are many steps before the ultimate goal is reached. Tom referred to this process as "conveyor belt science." Science works like a 
conveyor belt, he explained. There are many stages of research. It starts with the basic scientists and moves through various stages before a doctor can administer a drug to a patient. Each step builds on the work of the previous step, and so research moves along.

I use the metaphors of the map and the conveyor belt to conceptualize my research and to develop a writing style that mirrors the mapmaking of the scientific research that I observed. This article is written in "flashes". I borrow this style from Susan Levine's ethnography Children of a Bitter Harvest (2013). Commenting on her style, Levine writes, "Adapting the genre of flash fiction - which challenges writers to tell stories in 1000 words or less - to non-fiction has enabled me to give 'snapshots' of large themes in easily accessible and digestible forms" (Levine 2013, xxv). The flashes that chart the map of my research findings move the article along as if it were on a conveyor belt, building on each other sequentially until the reader makes meaning. Similarly, discussing the style of her article 'Skillful Revelation: Local Healers, Rationalists, and Their 'Trickery' in Chhattisgarh, Central India', Helen Macdonald writes, "If the article feels at times like a slow process of revelation then I acknowledge its intentionality... I position the reader intermittently within the aesthetics of revelation paradigm and as evidence of its resolve in guiding knowledge production of all sorts" (2015, 487). The article's structure of flashes aims toward this kind of revelation and knowledge production.

The style of flash ethnography also mirrors the scientific experiments that I observed: each experiment is made up of multiple stages, it occurs in multiple labs or spaces and it requires movement - whether movement from one stage to the next or movement between spaces. Perhaps the flashes also mirror the process of ethnographic fieldwork, where information comes in disjointed bits and pieces which are sewn together to make meaning, to create a map if you will.

Enjoy the conveyor-belt ride!

\section{Beyond the human: On multispecies ethnography}

Multispecies ethnography consists of anthropologists' research on both nonhuman species, ranging from marine microbes to popular companion species like dogs, and interspecies relationships between humans and nonhumans. Eben Kirksey and Stefan Helmreich introduce multispecies ethnography as an approach that decentralizes the human and centralizes creatures that are otherwise marginalized in anthropology $(2010,545)$.

Before conducting fieldwork, I imagined I would be encountering two species: the human and Mycobacterium tuberculosis. Little did I know that my project would be truly multispecies in that I would come into contact with various microbes and cells that play significant roles in TB research. E.coli is one of these. Tom told me that E.coli is called "the workhorse of the laboratory." They do a lot of the work for the scientists and are therefore incredibly important in TB research. They reproduce very quickly and according to Tom, "do not mind being messed with" on a genetic level. They are forced to take up the DNA of Mtb and reproduce it when they reproduce. Mycobacterium smegmatis is from the same family as Mycobacterium tuberculosis and because it grows faster than Mtb (and is not pathogenic) it is used to do preparation experiments before working with Mtb. Mycobacterium smegmatis can be used to get a sense of more or less what will happen with $M t b$, especially if it has been made to produce Mtb proteins. I also came into contact with Murine (mouse) macrophages. When infected, they reveal a close resemblance to what would happen when Mtb infects human macrophages. Lastly, I encountered two different fungi that were responsible for contaminating experiments. These fungi somehow managed to make their way into airtight containers and test tubes, taking over and ruining experiments.

Latour's discussion of ANT (2005) is central to multispecies ethnography. At its most basic, ANT redefines the social in order to trace associations and connections between actors $(2005,5)$. Latour argues that we cannot think of "groups" since "groups" suggest discrete 
entities; rather, we need to think about and work with "networks" (2005). If we start to look at the networks and connections that are brought into being around certain phenomena we can expand the definition of social. The new definition of social, Latour maintains, "has to be much wider than what is usually called by that name, yet strictly limited to the tracing of new associations and to the designing of their assemblages" $(2005,7)$. The social sciences, according to Latour, need to look at the full range of actors and what he calls "actants" or nonhuman agents (2005). Since humans do not exist in vacuums, but in multispecies relationships and networks, reading Latour pushed me to question why we place the human at the centre and to think about what our research could look like if we shifted positions to look at other creatures. By expanding the social I was able to conduct research with a subject that has been largely neglected in anthropological work. However, a few other scholars have considered microbes to be important anthropological subjects.

In her ethnography of a virus, Cecilia Lowe (2010) takes the H5N1 (avian influenza) epidemic in Indonesia as her starting point to explore the different networks that the virus brings into being. Lowe writes, "working to get beyond the human exceptionalism underlying much scholarship in anthropology and the humanities... I observed that H5N1 influenza brought together humans of diverse types (epidemiologists, chicken farmers, virologists, ornithologists, public health workers, government ministers) and equally diverse animals and strains of microbes" $(2010,629)$. In this sentence, Lowe provides an overview of the various nodes that form the network around $\mathrm{H} 5 \mathrm{~N} 1$. She also reveals how the H5N1 virus is deeply entangled not only in the local, but in the global; not only embedded in ecological and social realms, but in political and economic ones as well. Similarly, Helmreich's (2009) ethnography Alien Oceans: Anthropological Voyages in Microbial Seas is centred on a species that cannot be seen with the naked eye: marine microbes. Helmreich conducted five years of multi-sited ethnographic research among microbial oceanographers, biologists and other scientists as they used marine microbes for a number of studies ranging from monitoring climate to understanding other possible life forms on other planets. Helmreich brings microbes into the realm of agents that have very real effects on human life by exploring the complex networks and grand assemblages of which microbes are part. Both ethnographies push past the boundaries of anthropology's human-only approach to trace the connections and associations surrounding microbes.

To my knowledge, Erin Koch (2011) is the only other anthropologist to look at Mtb in a laboratory, though from a very different perspective to mine. Koch conducted six months of research with laboratory technicians who tested patients' sputum for active TB cases and drug susceptibility in order to provide them with case-appropriate drugs. Koch recognizes the relationship that forms between scientists and the microbe. She writes, "In a clinical TB laboratory, work is about cultivation, and cultivation is a relational process that emerges through and expresses social relations" (2011, 84). Koch's research looks at the paradox between the biomedical categorization of TB as a static state (either active or resistant) and the biological emphasis on its adaptability and resilience. The first understanding, which informs biomedical intervention, leads to rigid treatment regimens "which in turn could undermine the effectiveness of the very protocol designed to control the spread of disease and cure cases" (Koch 2011, 83). By using an anthropological lens to explore the molecular properties of the microbe, Koch's paper suggests that moving away from the discourse that classifies TB according to fixed states towards understanding it as variable will improve the intervention of infectious disease. While her research is largely centred on what understandings of the disease mean for policy, my own research is on the social relationship between humans and Mtb in a laboratory setting.

\section{4. "Fingeryeyes": Participant observation, or how I participated through observation and touched through sight}

Before I started my research in the Biosafety Level Three laboratory (BSL3) - a controlled 
environment in which my participants worked with this pathogen - I signed a form that stated I would only observe inside the lab. I could touch, and feel, the double pair of latex gloves that hugged my hands tightly. They irritated my skin and left marks on my wrists. I could feel the double elastic on the two arm-bands that covered each of my lower arms. I could feel the breathing machine attached around my waist. I could feel its weight and how it slipped against my back and pressed against my skin when I sat down. I could not move it without accidently opening the special gown that had to be worn inside BSL3 lab and I was not going to take that risk. I could feel the mask on my face and the cold air that blew into it and over my ears. I could feel the slippery floor against the scrubs that covered my shoes. I could feel the bottom of my jeans move up when I sat down and expose a slice of my skin. I could feel that spot of skin and I could feel my anxiety at its exposure. I could feel the pen between my fingers and the paper notebook that my hands grasped. These things, the things against my skin and wrapped around my body, I could feel very clearly. This was part of my embodiment, and brought me close to understanding and embodying the work that my participants did. But I could not touch experiments or participate in them. I longed to touch and to participate. In the beginning I noticed how I missed my sense of touch, how I wanted to be involved, to help and to feel what being a scientist felt like. Instead I developed another method, derived from Eva Hayward's ethnography, which allowed me to participate and touch.

Hayward's ethnography "Fingeryeyes: Impressions of Cup Corals" (2010) is based on her research conducted at a marine biology lab with Balanophyllia elegans - cup corals. Hayward's ethnography looks at the lives of coral in the lab and the relationship that forms between her and the coral, and to a lesser extent the marine biologists and the coral. Hayward's ethnography emphasizes the decentring of the human and the centring of the cup corals. "I found that just talking to cup coral experts... and being a participant-observer of routine laboratory tasks was not enough," Hayward writes $(2010,584)$. She creates the conceptual tool, the haptic-optic lens of fingeryeyes to navigate her sensual encounters with cup corals in the lab (2010, 580). Fingeryeyes is used to describe the kind of visual touch that occurs through the use of various mediums such as the camera and microscope to access worlds that "prostheticfree human experience" (Helmreich 2009, 15) cannot. Hayward's work is important because through developing a means by which she can conceptualize her interactions with nonhumans, she finds a creative way to translate her fieldwork encounters into visually rich language. This conceptual tool is beneficial to analyzing human-nonhuman encounters in a way that understands the shortcomings of merely applying the theory of encounters between humans. Hayward's fieldsite, her engagement with nonhuman organisms in a laboratory, her assertion of the organism's agency, her reconceptualization of humannonhuman encounters and her exploration of her relationship with the coral situate her project very close to mine.

I used fingeryeyes to come to know Mtb, to talk to it, to express my admiration for it, and to come to terms with my fear of it. In the beginning I did not meet the bugs through machinery, but with my eyes. Thus I extend Hayward's concept of fingeryeyes to encounters and experiences of microscopic beings through the human eye. One day Amy and I sat at a hood - formally known as a lamina-flow cabinet - inside the BSL3 lab. She explained that it was her fifth day of work, "so they have grown quite a lot now, so I need to dilute them." She was referring to the bugs that were floating inside the six culture flasks at the back of her hood. The flasks were lined up next to each other: three of the flasks had a beautiful pink-coloured liquid inside them and the other three were milky-coloured. Amy explained that each flask had a different strain inside it and each flask either had or did not have iron inside the culture. The milky-looking culture had iron and the pink-coloured culture had a compound that removed iron. In these flasks were millions of bacteria. The "thicker" the liquid looked, the more bacteria were inside. It was hard to believe that a deadly pathogen was swimming around in those liquids, eating, growing, reproducing, happy, warm and "having sex," as one of the senior scientists said to me. My fingeryeyes allowed me to meet the bugs, to 
touch them through my (eye)sight, but also my mind's-sight, since I had to use my imagination. They became more visible the longer I was in the field.

One morning I went with Jana into the BSL3 to see which of her cultures were growing. She took out one of the test tubes to show me and explained that inside the liquid are the bacteria. She turned the tube upside down and turned it up right again. She told me that the little things that looked like "breadcrumbs" in the liquid were the bacteria. It looked just like a snow globe, but instead of looking at a miniature scene of the Eiffel Tower I was looking at little bacteria that killed 1.4 million people in 2015 (World Health Organization 2016, 1). Through my fingeryeyes I encountered them again. Through sight I touched their snowy bodies as they floated around. I extend Hayward's concept of fingeryeyes even further, beyond encounters of prosthetic-free human experience, to situations where humans encounter microbes, but through the fingers of other humans. Using my eyes, and fingers that were not mine, I came to participate in laboratory processes and experiments through observation and touch through sight. Through fingeryeyes I sucked up the bacteria with a pipette and carefully placed them inside tiny little wells. Through fingeryeyes I placed the bugs on petri dishes and spread them out on the plate. Through fingeryeyes I picked up plates and counted three-week-old colonies of bacteria (see figure 2). Through fingeryeyes I touched and came to know Mycobacterium tuberculosis as babies.

\section{5. "They are my babies"}

It was my first day of fieldwork when the word "babies" came up. I was with Amy in the lab watching her spread the bugs out on the plate. While she moved the spreader smoothly across one of the plates she said to me,

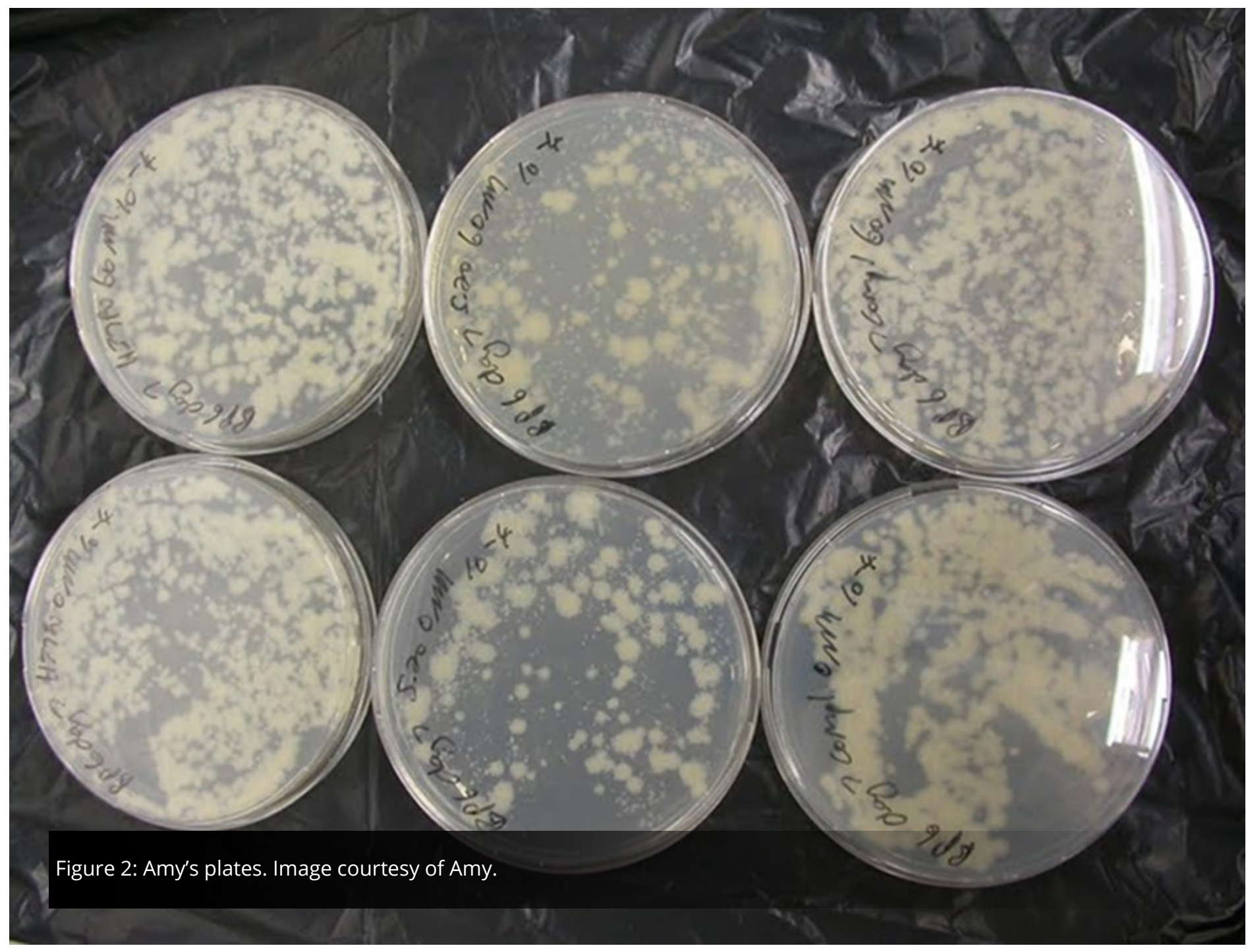


It may sound weird, but I love doing this. I need to take care of them. They are my babies. You have to give them their food. You have to make sure they are clean, that you put them into proper containers, that you put them properly on the plate so that they don't overcrowd... You must have a passion for it. Some people will laugh at me and find me weird, but I don't care.

It was the first time - and definitely not the last - that I heard Mtb being referred to as babies. Amy was not the only one who referred to her bacteria as babies. Nicole would call them her babies and I also heard an honours student calling her bacteria her babies. When I first heard this word I did not fully comprehend the extent to which Mtb had to be taken care of, but during my research I came to learn more and more about why they are considered babies. Like babies, Mycobacterium tuberculosis need to be conceived, fed, kept clean, warm and happy, and taken care of so that they grow. Christopher Mabeza writes, “Metaphors convey a deeper level of comprehension of meaning and significance" (2013, 131). Mabeza cites Kendall and Kendall who propose that metaphors are "cognitive lenses we use to make sense of meaning" (1993, 149 in Mabeza 2013, 131-2). The metaphor of babies helps to understand how scientists work with the bacteria. The "baby" is a lens through which my participants made sense of the demands of the bacteria for successful experiments.

There is a contradiction central to my work: deadly bacteria are considered human babies. The conceptualization of the bacteria as babies does not deny the devastation they cause. It is this devastation that has led to this scientific research in the first place. It must, however, be understood that Mtb is an organism that is merely trying to survive. This bug somehow manages to survive the harsh environment of the human macrophage, it does not mind being frozen, and it is "strong", "resilient", "brilliant" and "clever". These words came up a lot during my research.

Kylie Marais, in her dissertation "The
Ethnography of Leaks: What the Bodies and Bodily Fluids of Infants Reveal", writes, "Infants... enter into intimate care relationships - framed in large measure around feeding, comforting and tending to leaks - with various people from an early stage" $(2014,8)$. Like these infants, Mycobacterium tuberculosis relies on these relationships of care to survive in a laboratory environment. Without care in the form of feeding, cleaning, and keeping happy and warm, they would die. The environment of the laboratory paradoxically makes this a bug that requires nourishment and care, as you will read, and it is in this context rather than the body of the human that my research exists.

\section{Making babies/ making parents}

From my time at the TB research centre I learnt that depending on the research that scientists are doing, the bacteria do not necessarily come from people. They may have originally come from people, but they have been cultured and re-cultured in labs so many times that their once-human host is forgotten about. There are two major categories of Mtb strains: reference strains and clinical strains. Reference strains refer to laboratory strains, while clinical strains refer to strains from human hosts. There is one main reference strain (H37RV) and one main clinical strain (CDC1551) that scientists work with. The reason for this, as Tom explained to me, is that these two strains have been extensively characterized based on their genome and scientists therefore know how they grow and what their genome is like. This enables them to work on it. When a strain is taken from a patient, they do not know exactly what the genome looks like or how it grows. It is easier to do more work, or better work, on strains that are known and understood. The work done on these strains can still be applied to other strains, since the functions in the bacteria remain largely the same, as Tom explained. If the function is not the same then a whole different avenue of research is opened up. Tom tells me,

It's kind of like somebody decided this is the strain we're working on and then everybody said alright we'll work on this strain... It depends what you are working on. If you are looking at patient 
samples and how there are changes between patient strains then you work on the patient strains because that makes sense. If you are going to work on understanding the bacteria, you choose the reference strains because everyone's worked on them and built a knowledge base for those strains specifically. But whatever is found in those strains can still be applied to the clinical strains.

To bring these babies into being, my participants were given a "freezer stock" to begin with. Amy's strain (H37RV) was brought from Johannesburg and Tom was in the process of getting his strain (CDC1551) from Europe. No matter where they come from, the bacteria need to be conceived, cultivated or cultured from these small freezer stocks. Nicole explained the recipe for this conception:

1. Make food (otherwise known as broth or media) for the bacteria. It must be fresh and it must be made accurately. (The recipe for the food is in the "Making broth" flash.) The food is used to grow the bacteria.

2. Take the -80 degree Celsius freezer stock out of the freezer. The bacteria are frozen inside an "aliquot", which is a little test tube that contains 1000 microlitres of Mtb culture.

3. Thaw the stock at room temperature in the BSL3 or in a small incubator.

4. Once it has thawed, take the liquid inside the aliquot and put it with the food inside a small starter culture flask.

5. Put the culture flask inside a 37 degrees Celsius incubator.

6. Wait about one week for the bacteria to grow.

7. Once the bacteria have grown, put the culture into a bigger culture flask.

8. Put the culture flask into a 37 degrees Celsius incubator.

9. Wait about two weeks for the bacteria to grow.

10. You are now ready to start your experiment. Alternatively, you can make stocks from this culture.

The process goes a step further in the case of mutant making, where "mutants" of the bacteria have to be made in order to test certain aspects. Mutants are bacteria that have been manipulated or "messed with" on a genetic level. Since Amy, for example, is doing experiments to see what role iron has in growth, she made a mutant of her strain that is missing the protein involved in the incorporation of iron into other proteins in the bacteria. This requires conceiving your own baby, as Amy put it. When we were talking about her mutant, she said to me,

You have to take care of them and it's like I made the mutant, so I think it's a bit more of an emotional connection to the pathogen. I created this mutant. I don't think there's any mutant out there like this one, so it's like my baby. It's my new thing that I made, that I get to work on, but I made it myself.

Amy's response shows that making babies also makes parents. I am thinking here of Charis Thompson's book Making Parents: The Ontological Choreography of Reproductive Technology (2005). Thompson explores the making of parents through the making of "testtube babies" in assistive reproductive technologies (ARTs). "When they [reproductive technologies] work, they make babies and parents. These kinds of apparent contradictions are a signature aspect of assisted reproductive technologies. They are intensely technological, and yet they also make kinship" (2005, 4-5). In this flash in particular, what is common to both our work is the birth of organisms outside of the body and the kinship formed in a type of space that it is not usually associated with: the scientific laboratory. The making of parents means that my participants' relationship with this bacteria requires certain obligations such as care. Hayward asks, "Rather than passive surfaces reflecting human intention, might animals act upon us in surprising and nuanced ways?" (2010, 584). The making of the parent may be one answer to this question.

\section{Making broth}


Like babies, Mtb requires special food. It is called 7H9. This was explained to me as a "broth" that has all of the nutrients that Mycobacterium tuberculosis likes. "Broth" is a very interesting word for Mtb food, especially since it is generally (outside the lab) used to describe "thick soup made by boiling meat or fish and vegetables in water" (Wehmeier 2000, 139). "Broth" is more descriptive than merely "food" and suggests a nutrient-rich wholesome meal. This word is interesting to think about in light of the kinds of subject-making of Mtb.

Making the broth in the lab is quite a process. During my fieldwork I watched Nicole make it. When she started she said to me, "I'm making sure that my bacteria has nice food to grow in... we have to take care of it." She took a big empty glass bottle from the cupboard and told me that you need to use bottles that have been sterilised to avoid contamination in the form of other bacteria or fungi, which may be inside the bottle and contaminate the food. Microbes do steal food from each other; I witnessed a fungus that had taken over Amy's plates and another fungus that had found its way into a test tube that contained M.Smegmatis.

"I'm making sure that I'm going to feed it properly," Nicole told me, "The way to make your media is very important, every component of media has a function for the bacteria to grow." She took the broth from the shelf, measured the powder on a scale and filled the large glass jar with purified water before putting the powder inside. The water must be purified to avoid contamination or because normal water may contain a chemical that will affect the growth of Mtb. A sterilised lid is then put onto the bottle to seal it and tin foil is placed over the lid for extra sterility. The broth is stirred using a magnetic stirring machine and after this it is autoclaved, killing any bacteria or fungi that may be present. The process is not over yet. Nicole waited for the broth to cool down after being in the autoclave before she filter-sterilized it inside the hood using air pressure. The last step after filter-sterilisation was to add OADC - a growth enrichment - to the broth. Nicole told me that "OADC is like gold in this place." It makes Mtb grow more quickly and helps prevent contamination. She then closed the lid and shook the bottle to mix the OADC with the media. Finally, the broth was ready for the babies and it was put inside culture flasks to help them grow.

\section{Keeping your babies clean}

Marais, in her ethnography of leaks, argues that the relationships between the carers and the infants they looked after was formed around "tending to their leaks" in the form of "mucus, tears, urine, faeces and vomit" (2014, 7). Keeping the infants clean was thus essentially what their relationship was built on. Marais, writing about her own experience of keeping the infants clean, says,

My personal experience with infants' bodies and leaks varied across the days. Changing nappies involved undressing the infant and removing the infant's nappy, wiping the infant's genitals and buttocks clean with a wet cloth, rubbing the cleaned area with lotion, putting on a clean nappy and redressing the infant. Apart from that, tears, mucus and vomit were the primary leaks that I came into direct contact with. I spent a large portion of each day wiping tears from crying infant's faces, wiping mucus from infant's noses (and faces), and also wiping up vomit from the infant's clothing or the floor $(2014,26)$.

Mycobacterium tuberculosis, just like infants, needs to be kept clean. "You have to keep them clean", Amy and Nicole told me on multiple occasions. Keeping Mtb clean was also a vital process that required time and effort. Cleanliness had to do with contamination because contamination meant that experiments were ruined. In order to prevent contamination and keep the bugs "clean", the hood needed to be cleaned with distel before my participants started working inside it. Distel is a chemical that kills bacteria, fungi or other organisms and cells. Wiping the inside of the hood with it ensured that any organisms or cells that may have been inside the hood would be killed. "It is true that the death of some is the 
life of others" writes de Castro (2014, 33). Although taken out of context, this sentence has resonance here. There is death in the lab in order for there to be life. De Castro views this condition as "the principal of the conservation of energy" (2014, 33). Life and death coexist in inseparable ways; this is the cycle of life and for microbes in the laboratory this cycle is very short.

Everything that went into the hood was sprayed and wiped down with ethanol before it entered the hood. This was to protect Mtb from other bacteria or fungi and from the human: "It's about protecting yourself, but also protecting them [the bacteria]," Amy told me. There was a notion of mutual cleanliness that Amy stressed all the time. I also saw this when working with my other participants. They needed to keep their bacteria clean, but that also involved keeping themselves clean by ensuring they were dressed correctly and that their gloves were sprayed with ethanol each and every time they put their hands inside the hood. Furthermore, in order to keep Mtb clean, the bacteria were kept in zip-lock, air tight bags inside sealed, airtight containers and their food was constantly checked for contamination (this was done through sight). "I can see if a culture has been contaminated," Amy said.

Amy was very worried about contamination. One day she fetched a large plastic zip-lock bag. Inside were two big glass bottles and a few smaller test tubes. The clear liquid inside the large bottles was the saline solution that was used to dilute the cultures. The small test tubes also contained this solution, but Amy insisted on making a new solution each time she wanted to dilute her cultures just in case they got contaminated. "It's disheartening to see your culture is contaminated, you have to throw everything away," Amy told me before she held each tube up and gently shook the saline




solution. She also held the large glass bottle up to the light and looked at it carefully. Staring at her bottles and test tubes, she explained that a few days ago she thought she saw "something funny" in the saline solution. Looking at it again, she said it seemed fine, but just to be safe she made a new tube of the solution. Amy was set on keeping her babies clean. In fact, she told me about an incident where she feared for her babies' cleanliness more than her safety:

One afternoon the electricity tripped in the BSL3. If the electricity trips, the hoods, which run on electricity, stop working. This means that there is no controlled air flow that ensures that particles do not escape out of the hood or that the particles outside the hood do not get inside. Usually a replacement generator kicks in immediately, but that day it did not. Amy was drying out her plates, which is quite risky even with a working hood because it involves opening up plates that are covered in Mtb colonies. She explained to me that she was more scared of her plates getting contaminated by other organisms moving into the hood than she was of Mtb moving out of the hood.

After a few weeks one of her plates from this set was indeed contaminated. I was with Amy in the lab when she went to the incubator to fetch a set of plates that she needed to dry out because they were quite wet. When she brought the tupperware to the hood and opened up one of the plastic bags, we saw a furry brown fungus on each of the plates in that set. Amy had to throw out all of the contaminated plates. After seeing this she was so worried about her other plates that she wanted to come in over the weekend to check on them.

A lot of work goes into ensuring that the bacteria are kept clean. When I was with Nicole in the walk-in freezer she said to me, "you don't want your babies to get contaminated; you don't want your babies not to grow."

\section{Keeping them happy: "TB needs friends"}

I was sitting in the lab with Tom while he was doing an experiment. We were talking about the E.coli inside a small test tube on his bench. Tom told me that they were "competent cells", which means "they have been made ready." After seeing my blank expression, he added, "So they have holes in them so that the DNA will move into the cell more regularly." He was talking about the DNA from Mycobacterium tuberculosis and how E.coli is "made" to reproduce that DNA when they reproduce, thus giving scientists an ample amount of Mtb DNA to use in experiments. Tom went on to tell me that the punctured E.coli are given SOC (Super Optical Broth with Catabolite Repression). It is a liquid that contains nutrients. Tom said to me, "I give them nutrients to keep them happy; if they are happy you get results." Tom's answer probed me to ask, what makes Mtb happy? "With TB," he replied, "TB needs friends... this is how I explain it to my honours students... If you add a small amount of $M t b$ to a large volume they won't grow because Mtb needs friends around it. They need this interaction... It's part of their lifestyle to clump" (see figure 3).

Mtb is a social being; it has a sticky cell wall and likes to clump. Stickiness was a problem when it came to plating the cultures. "They stick together like crazy... to get them away from each other is quite challenging," Amy told me on my first day of doing fieldwork with her. You need to add a detergent to the bacteria to make them less sticky, she explained. If they stick together when they are plated, it interferes with counting colonies at the end of the experiment. One colony is when one bacillus has reproduced on the spot. If two or three bacilli land on one spot and reproduce then the counting of the subsequent colony as one colony is inaccurate. This clumping was made visible on some of Amy's plates.

We were in the BSL3 counting the colonies on some of Amy's plates. After a while of her picking up various plates and looking at them I noticed that she looked confused and upset. She showed me that there was quite a big difference in the size of the colonies (see figure 2). I looked at the plates and saw that some colonies were large while others were so small that they looked like little bubbles. Amy explained that when the bacilli were plated, they had clumped together even though she had used the detergent to split them up. "I'm a bit disappointed," Amy said as she shook her head and looked down at her plates. She picked 
them up one at a time and scrutinized each one again. "I thought they would separate nicely," she said. Before I had time to feel sorry for her, Amy's bubbly personality picked her back up again. She looked at me and started laughing, "They have separation anxiety!"

\section{0. "Separation anxiety"}

"You get so attached to them," Nicole told me when she was making the broth for the bacteria. I was well versed in the attachment after being in the lab with Amy. In my interview with Amy we spoke a lot about this separation anxiety, though not in these exact terms:

I've been keeping them for too long! It's very difficult for me to throw them out on the plates. I think that's because they take so long to come up and then you think, 'I may need them again for something,' but you don't actually need them! I'm one of those people that like storing stuff though, just with normal stuff as well I may use them again. It's like that with the plates as well... You have been working so hard on growing them, this has been so much work and then it ends up being in a bag in the autoclave... that's all my work that's in there. You have a result, but it's still all your work that's in there.

When I worked with Nicole I saw the same thing. I was sitting next to Nicole at the hood while she was sorting out her plates before she threw them away. "The one thing about scientists is that we are scared of throwing our samples away. We don't want to throw anything away... Sometimes you will go to the bin to look for a plate!" she told me, smiling. She knew that she needed to throw the plates out, but she did not want to. On my last day with Nicole she looked at her culture flasks and said to me, "I have a problem. I don't want to throw them away, but I have to. I'm working on my problem."

Although the resistance to "throw away" bacteria reveals the "sticky attachment" (Haraway 2008) that my participants had for their bacteria, it simultaneously reveals the limitations of the kinship and human growth metaphor alluded to throughout this article. Babies would not grow into children: their life course ends before it even begins, revealing the asymmetrical power relations between human and microbe. Haraway reminds me of this asymmetry when she writes about her dog, "I know very well how much control of Cayenne's life and death I hold in my inept hands" $(2008,216)$. But I do remind the reader that it was not easy to throw the bacteria away. My participants would hoard the bacteria inside the incubator because they could not bring themselves to throw them away. This does complicate any simple remark that the bacteria were disposable. I argue that care was a way to redress the fact that Mtb did not consent to being involved in this relationship.

My participants' caring formed a mutualistic relationship which allowed both the bugs and them to flourish. Indeed, these bugs were "killed" at the end of the experiments, but during their life they benefited from my participants. They were given everything that they liked: nutrient-rich food, an environment that was not trying to kill them (as the macrophage does), warm temperature, and friends. I quote Tom, "If you understand that they are living organisms you do much better science." There is a genuine sense of care in the research that happened in the laboratory and a deep understanding that my participants were working with living organisms who (yes, "who") deserved respect. The caring was intrinsic to what they did as scientists. More specifically, through conceptualizing the bacteria as babies, care relationships were obligatory.

\section{1. "When they grow you dance": On flourishing}

Just like babies, Mycobacterium tuberculosis needs to grow. This is why they were given food, kept clean - which meant keeping other bacteria or fungi out so that they did not steal the food - and kept nice and warm at thirtyseven degrees Celsius inside an incubator. Mycobacterium tuberculosis is slow growing. Inside the human body it can take months to develop into a disease. In the lab it can take weeks for it to grow to the point that my 
participants required for their experiments.

Growth is vital for experiments to work. The bugs need to grow so that cultures can be made and they need to grow on plates in order for colonies to be counted. Nicole told me that sometimes she just wanted to go into the BSL3 to check on her plates, "I just need to see how my babies are doing," she said. This checkingup made me think about the need that led to the invention of the baby monitor, so that parents would not have to constantly check up on their babies and the checking-up on growth reminded me of the monitoring of a baby's growth whether by parents, caregivers or nurses and doctors.

Talking about the growth of Mtb, Nicole said to me, "It teaches you patience, because they take so long to grow." This idea of being taught patience reveals a deeper connection between the bug and a baby. "When the bugs don't grow well you cry. When they grow you dance," Nicole said. Since Mtb take so long to grow, it is understandable that growth would mean joy and lack of growth, heartache. Nicole's statement reveals the kind of emotional investment in the growth of the bacteria. Amy also expressed the long wait, the joy at the end of it and the emotional investment in growth:

It's not the same thing when working with E.coli for instance because that you can see in a day. But it's not as fascinating as waiting three weeks and then you see them! So I guess the fact that you have to nurture them and they take such a long time, and then you see something and then eventually they get so big on the plate!

What I found fascinating was that, like babies, each strain grows at a different pace. Inside the BSL3 I observed Nicole measuring the growth rate of her different strains, each in its own tube. She took one tube at a time, put it inside a little opening in a machine, closed the lid of the machine and the machine gave a reading. She wrote down each reading and then said to me, "My babies are growing very well, except that one of them is a slow grower." Whenever Nicole spoke about the growth of the bug she compared it to the growth of a child, further enhancing the connection between babies and microbes. Nicole told me that when she and Amy were in the lab together they would ask each other if they had sung to their bacteria to help them grow, making further connections between babies and Mycobacterium tuberculosis.

In relation to multispecies ethnography, the concept of flourishing seems important here. Flourishing is an ethical starting point central to ecological feminism (Cuomo in Haraway 2008, 134). Haraway writes, "Feminists have also argued early, often, and well for caring in all its senses as a core needed practice" $(2008,332)$. When Haraway asks Michael Hadfield, a zoologist, how he knows his animals are not flourishing he answers, "Ah, well, that's usually when they die" (2008, 90). Flourishing is growing, it is surviving and it is thriving. But what does flourishing mean for different species in companion (Haraway 2008, 41)? There is a very sad paradox here: inside the body, flourishing Mtb means the human's failure to flourish. In fact, an infant's "failure to thrive" is a signifier that they may have Tuberculosis (World Health Organization 2012).

In the lab, however, if the bacteria flourish, so do the experiments, as do the scientists.

\section{Caring for them = caring for me = caring for science: Concluding thoughts}

The relationship between my participants and the bugs that they work with was characterized by care. The word "care" constantly came up during my fieldwork. The theme of care reveals the nurturing that happens behind the scenes of science experiments. Caring for $M t b$, however, was also about caring for my participants. There was a sense of reciprocity between my participants and Mtb: if the bacteria were taken care of correctly, they would give the required results. Caring, then, equals better science. This idea also surfaced when Nicole described the relationship between her and the bug as a "mutualistic relationship." The mutualistic relationship allowed both the scientists and the bugs to flourish. 
Kirksey and Helmreich write about Caitlin Berrigan's performance art at the Multispecies Salon Art Exhibition, which was put up for the 2008 American Anthropological Association (AAA) Annual Meeting:

Playing with popular anxiety surrounding microbial becomings, performance artist Caitlin Berrigan created a series of sentimental objects in an attempt to "befriend a virus." Growing tired of the rhetoric of war commonly used by health care workers to describe her illness, hepatitis C, Berrigan, who carries the virus in her blood, performed what she called a "nurturing gesture," at the Multispecies Salon. Drawing her own blood, she offered it to a dandelion plant as a nitrogen-rich fertilizer. $(2010,560)$

Moving away from the anxiety surrounding Mycobacterium tuberculosis and trying to explore the other attachment sites in which the bacteria exists, I attempted to view it in other ways and through other kinds of lenses, being aware of both its horror and its beauty, both its agency and its vulnerability, both its violence and its need for care. In befriending a virus, Berrigan turns into a friend what would otherwise be seen as an enemy and in this way reconceptualizes her relationship with the virus. This article has been about reconceptualizing the scientists' relationship with Mtb. In the same way that Berrigan gives her blood to the dandelion, a nurturing and nourishing gesture, I present the relationship between Mycobacterium tuberculosis and four humans to you, the reader, in the hopes that it may enrich your understanding of the multispecies relationships, entanglements and webs in which humans are involved. With this said, I hope that some readers are inspired to conceptualise research projects that expand their parameters to include the multitude of cells, organisms, critters and creatures which are so central to human worlds. This would indeed make fruitful and flourishing contributions to moving beyond the human in the humanities and extending the social in the socialsciences. 


\section{Acknowledgements}

I would like to acknowledge the scientific research centre in which I conducted my fieldwork and the scientific researchers for their participation in this project. I would also like to acknowledge the University of Cape Town for their funding assistance and the National Research Foundation (NRF) and Wellcome Trust for funding assistance towards two conferences in which versions of this article were presented. 


\section{References}

Benezra, Amber, DeStefano, Joseph, and Gordon, Jeffrey. 2012. "Anthropology of Microbes." Proceedings of the National Academy of Sciences of the United States of America 109(17): 6378-6381.

de Castro, Eduardo Viveiros. 2004. “Exchanging Perspectives: The Transformation of Objects into Subjects in Amerindian Ontologies." Common Knowledge 10(3): 463-484.

de Castro, Eduardo Viveiros. 2014. "Economic development and cosmopolitical re-involvement: From necessity to sufficiency." In Contested Ecologies: Dialogues in the South on Nature and Knowledge, edited by Lesley Green, 28-41. Cape Town: HSRC Press.

Geertz, Clifford. 1998. "Deep hanging out." The New York Review of Books 45(16): 69-72.

Haraway, Donna. 2008. When Species Meet. Minneapolis: University of Minnesota Press.

Hayward, Eva. 2010. "Fingeryeyes: Impressions of Cup Corals." Cultural Anthropology 25(4): 577-599.

Helmreich, Stefan. 2009. "Introduction: Life at Sea." In Alien Ocean: Anthropological Voyages in Microbial Seas, 1-30. Berkley: University of California Press.

Kirksey, Eben, and Helmreich, Stefan. 2010. "The Emergence of Multispecies Ethnography." Cultural Anthropology 25(4): 545-576.

Koch, Erin. 2011. "Local Microbiologies of Tuberculosis: Insights from the Republic of Georgia." Medical Anthropology30(1): 81-101.

Latour, Bruno. 2005. Reassembling the Social: An Introduction to Actor-Network-Theory. Oxford: Oxford University Press.

Levine, Susan. 2013. Children of a Bitter Harvest: Child Labour in the Cape Winelands. Cape Town: Bestred.

Lowe, Cecilia. 2010. "Viral Clouds: Becoming H5N1 in Indonesia." Cultural Anthropology 25(4): 625-649.

Mabeza, Christopher. 2013. "Metaphors for climate change adaption from Zimbabwe: The marriage of water and soil." In Contested Ecologies: Dialogues in the South on Nature and Knowledge, edited by Lesley Green, 126-137. Cape Town: HSRC Press. 
Macdonald, Helen. 2015. "Skillful Revelation: Local Healers, Rationalists, and Their 'Trickery' in Chhattisgarh, Central India." Medical Anthropology 34(6): 485-500.

Marais, Kylie. 2014. "The Ethnography of Leaks: What the Bodies and Bodily Fluids of Infants Reveal." Honours diss., University of Cape Town.

Thompson, Charis. 2005. Making Parents: The Ontological Choreography of Reproductive Technologies. Cambridge: MIT Press.

Tsing, Anna. 2012. “Unruly Edges: Mushrooms as Companion Species." Environmental Humanities 1: 141-154.

Wehmeier, Sally, ed. 2000. Oxford Advanced Learner's Dictionary: Sixth edition. Oxford: Oxford University Press.

World Health Organization (WHO). 2012. "Childhood tuberculosis neglected, despite available remedies: Childhood TB is a hidden epidemic." Accessed November 13 2016. http://www.who.int/ mediacentre/news/releases/2012/tb_20120321/en/.

World Health Organization (WHO). 2016. "Global Tuberculosis Report Executive Summary 2016." Accessed November 16 2016. http:// www.who.int/tb/publications/global_report/ gtbr2016_executive_summary.pdf. 